\title{
Body adiposity indices are associated with hypertension in a black, urban Free State community
}

\author{
Authors: \\ Ronette Lategan ${ }^{1}$ \\ Violet L. van den Berg ${ }^{1}$ \\ Corinna M. Walsh ${ }^{1}$

\section{Affiliations:} \\ ${ }^{1}$ Faculty of Health Sciences, \\ University of the Free State, \\ South Africa \\ Correspondence to: \\ Ronette Lategan \\ Email: \\ nutrition@ufs.ac.za \\ Postal address: \\ PO Box 339 (G24), \\ Bloemfontein, 9300 \\ South Africa \\ Dates: \\ Received: 13 Aug. 2013 \\ Accepted: 28 Nov. 2013 \\ Published: 19 May 2014 \\ How to cite this article: \\ Lategan R, van den Berg VL, \\ Walsh CM. Body adiposity \\ indices are associated with \\ hypertension in a black, \\ urban Free State community. \\ Afr J Prm Health Care Fam \\ Med. 2014;6(1), Art. \#581, \\ 7 pages. http://dx.doi. \\ org/10.4102/phcfm.v6i1.581

\section{Copyright:} \\ (C) 2014. The Authors. \\ Licensee: AOSIS \\ OpenJournals. This work \\ is licensed under the \\ Creative Commons \\ Attribution License.
}

Background: Non-communicable diseases, including hypertension, are increasing rapidly in resource-poor, developing countries amongst populations transitioning from traditional to westernised lifestyles; and are associated with excess weight.

Aim: To investigate the relationship between hypertension and various indices of body adiposity in a transitioning, urban, black population.

Setting: Three hundred and thirty-nine adults (25-64 years) from a larger cross-sectional study (Assuring Health for All in the Free State) conducted in Mangaung, South Africa, were included.

Methods: Standard techniques were used to determine blood pressure, HIV status, body mass index (BMI), waist-to-height ratio (WHtR) and body adiposity index (BAI).

Results: Approximately $40 \%$ of the sample was HIV-positive and $63.4 \%$ hypertensive, with the greatest risk of hypertension being amongst older men. Based on BMI, 23.0\% were overweight and $32.1 \%$ obese. Waist-to-height ratio showed that $58.6 \%$ had increased cardiovascular risk. Mean BAI was 34.1\%, whilst $76.3 \%$ had a body fat percentage in the overweight/obese category. Waist circumference representing increased cardiovascular risk was found in $44.3 \%$ of women and $3.9 \%$ of men. Significant positive correlations between mean arterial blood pressure and BMI $(r=0.261 ; p<0.001)$, WHtR $(r=0.357 ; p<0.001)$ and BAI $(r=0.245 ; p<$ $0.001)$ were found. WHtR was a stronger predictor of mean arterial pressure than BMI or BAI. HIV status showed an inverse correlation with all adiposity indices $(p<0.001)$.

Conclusion: Our findings promote WHtR as a practical screening tool for increased hypertension risk in populations undergoing westernisation, and support weight loss as a first-line intervention for the prevention and management of hypertension.

Les indices d'adiposité corporelle sont associés à l'hypertension dans une communauté africaine et urbaine de la province de l'Etat libre.

Présentation: Les maladies non transmissibles, notamment l'hypertension, connaissent une augmentation rapide dans les pays aux ressources limitées et en voie de développement parmi les populations en transition entre un style de vie traditionnel et un style de vie occidentalisé; elles sont également associées à un excédent de poids.

Objectif: Etudier la relation entre l'hypertension et différents indices d'adiposité corporelle dans une population africaine, en transition et urbaine.

Cadre: Trois cent trente-neuf adultes (âgés de 25 à 63 ans) sélectionnés à partir d'une étude transversale de plus grande envergure (Assurer la Santé pour Tous dans l’Etat Libre) réalisée à Mangaung, en Afrique du Sud, ont été inclus.

Méthodes: Des techniques standards ont été utilisées afin de déterminer la tension artérielle, la séropositivité, l'indice de masse corporelle (IMC), le rapport taille-hanche (RTH) et l'indice d'adiposité corporelle (IAC).

Résultats: Environ $40 \%$ de l'échantillon étaient séropositifs et $63.4 \%$ étaient hypertensifs, le risque d'hypertension le plus élevé étant observé chez les hommes âgés. Sur la base de l'IMC, $23 \%$ étaient en surpoids, et 32.1 étaient obèses. Le RTH indiquait que $58.6 \%$ présentaient un risque cardiovasculaire accru. L'IAC moyen était de $34.1 \%$, et $76.3 \%$ des participants à l'étude avaient un pourcentage de graisse corporelle entrant dans la catégorie surpoids/ obèse. La circonférence de la taille représentant un risque cardiovasculaire accru a été mesurée à $44.3 \%$ chez les femmes et à $3.9 \%$ chez les hommes. Des corrélations significatives entre la tension artérielle moyenne et l'IMC $(r=0.261 ; p<0.001)$, le RTH $(r=0.357 ; p<0.001)$ et l'IAC $(r=0.245 ; p<0.001)$ ont été observées. Le RTH était une variable causale plus importante de la tension artérielle moyenne que l'IMC ou l'IAC. La séropositivité présentait une corrélation inverse avec tous les indices d'adiposité $(p<0.001)$.

Conclusion: Nos conclusions indiquent que le RTH devrait être utilisé comme outil de dépistage pratique du risque d'hypertension accru chez les populations en transition, et que la perte de poids devrait être recommandée comme intervention de première ligne pour la prévention et la gestion de l'hypertension. 


\section{Introduction}

Hypertension is a leading cause of morbidity in middleincome countries. It is gaining significance in low-income countries, contributing to an increasing global disease burden. ${ }^{1,2}$ Underdiagnosis and/or inadequate treatment of hypertension may cause organ damage and premature death, ${ }^{1,3}$ affecting the economy of a country and making prevention and early intervention important objectives for health authorities worldwide.

It has been estimated that hypertension accounted for $9 \%$ of deaths in South Africa in 2000, making it the second-highest cause of mortality after sexually-transmitted diseases. ${ }^{2}$ South Africa has been undergoing a transition from traditional diets and more active lifestyles to typically Western diets and more sedentary practices. These trends are associated with the high prevalence of obesity amongst black South Africans, particularly women in urban areas. ${ }^{3}$

A strong relationship exists between body weight and blood pressure, with the risk of developing hypertension being two to six times higher in overweight than in normal weight individuals. ${ }^{1}$ Overweight and general adiposity are associated independently with an increased risk for heart failure. ${ }^{4}$ A strong relationship also exists between the degree of obesity as measured by body mass index (BMI) and waist circumference (WC), and the prevalence of ischaemic stroke, regardless of gender or race. ${ }^{5}$ Weight loss as a first-line treatment for lowering blood pressure is therefore generally recommended. ${ }^{1,3,6,7}$ It has been found that $5.1 \mathrm{~kg}$ of weight loss caused a reduction of $4.44 \mathrm{mmHg}$ and $3.57 \mathrm{mmHg}$ in systolic and diastolic pressure, respectively, translating to a reduction of $1.05 \mathrm{mmHg}$ in systolic and $0.92 \mathrm{mmHg}$ in diastolic pressure per kilogram of weight lost. ${ }^{7}$ Markers of general obesity and indicators of abdominal obesity are good predictors of cardiovascular risk. Waist circumference (WC), waist-to-height ratio (WHtR), BMI and visceral fat percentage are strong predictors of arterial stiffness in morbidly obese female patients. ${ }^{8}$

The World Health Organization (WHO) recognises two thresholds for abdominal obesity as measured by WC, depicting different levels of risk for metabolic (including cardiovascular) complications. Increased risk is at a WC of $>80 \mathrm{~cm}$ in women and $>94 \mathrm{~cm}$ in men, with substantially increased risk at a WC of $>88 \mathrm{~cm}$ for women and $>102$ $\mathrm{cm}$ for men. ${ }^{9}$ Even a WC within the higher parameters of normal cut-off points is associated with a high prevalence of hypertension in older adults, independent of BMI and other hypertension risk factors. ${ }^{10}$

The risk for metabolic complications occurs at different levels of adiposity (indicated by BMI) and central obesity (indicated by WC) in different populations. It has been recommended that the current BMI cut-off points should be retained as international classification, but that more detail be added for reporting purposes $\left(18.5 \mathrm{~kg} / \mathrm{m}^{2}-23 \mathrm{~kg} / \mathrm{m}^{2}\right.$ increasing but acceptable risk; $23 \mathrm{~kg} / \mathrm{m}^{2}-27.5 \mathrm{~kg} / \mathrm{m}^{2}$ increased risk; and $\geq$
$27.5 \mathrm{~kg} / \mathrm{m}^{2}$ high risk) to facilitate international comparison. ${ }^{11}$ Different ethnicity-specific cut-off points have also been suggested for WC. ${ }^{12}$

As no ethnicity-specific WC recommendations exist for South Africans, the recommendations for sub-Saharan Africa ${ }^{13,14}$ ( $80 \mathrm{~cm}$ for women; $94 \mathrm{~cm}$ for men) can be considered, which are approximately $10 \%$ lower than the recommendation for North Americans. ${ }^{12}$

WHtR is regarded as a better and more sensitive obesity marker than BMI for predicting hypertension and as an early marker of metabolic health risks. ${ }^{15,16}$ An advantage of WHtR is that the same cut-off point (0.5) can be used for both men and women of different ethnic groups. ${ }^{15}$

Body adiposity index (BAI), a direct estimate of percentage body fat calculated from hip circumference and height, is an easily-obtained measure to predict the risk for obesityrelated diseases. ${ }^{17}$

Despite strong evidence that supports the association between body weight and hypertension, Schutte et al. ${ }^{18}$ failed to show a strong relationship between obesity markers (BMI and fat percentage) and blood pressure amongst black South African women.

The high prevalence of HIV infection in South Africa should be considered. Hypertension is equally common amongst both HIV-infected and -uninfected individuals. Although multivariate models link increasing age, higher BMI, longer duration of infection and diabetes to hypertension in HIVinfected populations, the prevalence of hypertension is apparently not influenced by HIV status or the use of highly active antiretroviral therapy (HAART). ${ }^{19,20,21,22,23}$

The Assuring Health for All in the Free State (AHA-FS) study investigated the double burden of infectious diseases and undernutrition, on the one hand, and obesity and its comorbidities on the other, in a low-income, black, urban community in central South Africa. Hypertension occurred in $56.9 \%(n=415)$ of the study population and mean systolic and diastolic blood pressure measurements were 135.5 $\pm 23.9 \mathrm{mmHg}$ and $89.8 \pm 17.4 \mathrm{mmHg}$, respectively. ${ }^{24}$ The high prevalence of hypertension in this population was the motivation for investigating its primary causes. The objective of this substudy, therefore, was to invesitgate to investigate the relationship between blood pressure and various indices of body adiposity (BMI, WC, WHtR and BAI) in a transitioning urban black population, whilst taking into account the influence of HIV.

\section{Research methods and design}

Approval to conduct the study was obtained from the Ethics Committee of the Faculty of Health Sciences, University of the Free State in Bloemfontein, South Africa.

For this cross-sectional study, data from the urban AHAFS study ${ }^{24}$ were used. Data were collected over a period 
of two weeks in March 2009 from six areas in Mangaung, South Africa, namely Freedom Square, Turflaagte, Namibia, Kagisanong, Chris Hani and Rocklands. Households were selected by proportional cluster sampling, stratified by area and formal plot/squatter households in open areas. Using randomly selected X- and Y-coordinates, 100 starting points were selected. Trained field workers approached five adjacent households from each starting point in order to obtain written informed consent from eligible adults (25-64 years). In the AHA-FS study, a variety of measurements, including body weight, height, waist and hip circumferences were taken, blood pressure was measured and blood samples were drawn for various biochemical tests. A subsample, with complete data sets for age, gender, blood pressure, body weight, height and HIV status, was included in this study.

Blood pressure was measured by a registered medical practitioner according to recognised guidelines. ${ }^{25,26}$ Hypertension was defined as systolic blood pressure of $\geq$ $140 \mathrm{mmHg}$ and/or diastolic blood pressure $\geq 90 \mathrm{mmHg} .{ }^{1}$ Participants using prescription medication for the management of hypertension at the time of the interview were also classified as hypertensive..$^{25,26}$

HIV status was determined from fasting venous blood samples. Primary screening for HIV was performed using the Enzygnost HIV Integral II Ag/Ab test (Dade Behring, Marburg, Germany) and results were confirmed by the Vironostika HIV Uni-Form II Ag/Ab test (bioMérieux, Marcy l'Etoile, France).

Anthropometric measurements were taken by trained finalyear Dietetics students, under supervision of the researchers. Body weight was determined using WHO guidelines ${ }^{27}$ on a floor-type Seca 770 digital scale (Medical Scales and Measuring Systems Seca kk., Japan) with accuracy to $100 \mathrm{~g}$ and a maximum capacity of $200 \mathrm{~kg}$. Height was measured ${ }^{27}$ with a Seca stadiometer (Medical Scales and Measuring Systems Seca kk., Japan) accurate to the nearest $5 \mathrm{~mm}$. BMI $\left(\mathrm{kg} / \mathrm{m}^{2}\right)$ was calculated and interpreted according to WHO guidelines. ${ }^{27,28}$ Waist circumference was measured with a non-stretch measuring tape, midway between the top of the superior iliac crest and the lowest rib in the mid-axillary line. ${ }^{9}$

Waist circumference was interpreted according to WHO guidelines ${ }^{9}$ as increased risk of metabolic complications at $>$ $80 \mathrm{~cm}$ in women and $>94 \mathrm{~cm}$ in men; and as a substantiallyincreased risk of metabolic complications at a WC $>88 \mathrm{~cm}$ in women and $>102 \mathrm{~cm}$ in men. WHtR was determined by dividing WC $(\mathrm{cm})$ by height $(\mathrm{cm})$. A WHtR of $\geq 0.5$ indicates an increased risk for non-communicable diseases (NCDs) in both genders. ${ }^{15}$

Hip circumference was measured at the widest portion of the buttocks parallel to the floor, accurate to the nearest $5 \mathrm{~mm} .^{27}$

Hip circumference and height were used to calculate BAI (see formula below) ${ }_{17}^{17}$ which provides an accurate estimate of body fat percentage when compared to dual-energy X-ray absorptiometry (DXA). ${ }^{17}$
BAI $(\%$ body fat $)=$ hip circumference $(\mathrm{cm}) \div$ height $(\mathrm{m})^{1.5}-18$. BAI results were interpreted according to the classification proposed by Ricciardi et al..$^{29}$ namely:

- low body fat: $10 \%$ - 15\% (men); $14 \%$ - 20\% (women)

- average body fat: $16 \%$ - $18 \%$ (men); $21 \%$ - 25\% (women)

- above average body fat: $19 \%-20 \%$ (men); $26 \%-29 \%$ (women)

- overweight body fat: $21 \%-25 \%$ (men); $30 \%-35 \%$ (women)

- obese body fat: $\geq 26 \%$ (men); $\geq 36 \%$ (women).

\section{Statistical analysis}

Analysis of data was performed with PASW (Predictive Analytics SoftWare) statistics software by SPSS version 18 (Chicago, SPSS Inc.). Frequencies and percentages were used to express categorical data. Means and standard deviations, or percentiles, as appropriate, were used to express quantitative variables. Comparisons of means were performed using $t$-tests. Chi-square tests, two-tailed Pearson correlations, point bi-serial correlations and multivariate logistic regression models were used to describe and test associations between variables; and relative risk of incidence was calculated.

\section{Ethical considerations}

Ethical clearance was granted by the Ethics Committee, Faculty of Health Sciences, University of the Free State, Bloemfontein, South Africa (ETOVS number 21/07).

\section{Results}

\section{Age, blood pressure, anthropometry and HIV status}

A total of 339 adults (76 men [22.4\%]; 263 women [77.6\%]) with a mean age of 44.3 years (range 25-64 years) were included in the study. Table 1 summarises the participants' information in terms of age, blood pressure (systolic, diastolic and mean arterial pressure) and anthropometry.

More than a third $(39.8 \% ; n=135)$ of the sample was HIV-infected and the mean BMI was significantly lower $(p<0.001)$ in HIV-infected participants $\left(24.9 \pm 7.4 \mathrm{~kg} / \mathrm{m}^{2}\right)$, compared with HIV-uninfected participants $(29.6 \pm 9.2 \mathrm{~kg} /$ $\left.\mathrm{m}^{2}\right)$. In $41.6 \%(n=141)$ of individuals, systolic blood pressure was $\geq 140 \mathrm{mmHg}$, whilst $46.6 \%(n=158)$ had a diastolic blood pressure of $\geq 90 \mathrm{mmHg}$, indicating hypertension. Approximately one quarter $(25.4 \% ; n=86)$ of participants used antihypertensive medication at the time of the study. Consequently, 63.4\% (57.9\% [ $n=44]$ men and 65.0\% $[n=171]$ women) of the participants were classified as hypertensive.

\section{Distribution of body fat indices}

The distribution of body fat indices of the participants is summarised in Table $2 \mathrm{~A}, \mathrm{~B}, \mathrm{C}$ and D.

Based on BMI, $18.4 \%(n=14)$ of the men and $65.8 \%(n=173)$ of the women were overweight/obese. With regard to WC, 
using cut-off points for sub-Saharan populations, 6.5\% $(n=5)$ of the men $(\mathrm{WC}>94 \mathrm{~cm})$ and $66.8 \%(n=175)$ of the women $(\mathrm{WC}>80 \mathrm{~cm})$ showed increased health risk.

An overweight/obese BMI was associated significantly $\left(\chi^{2}=144.533 ; p<0.001\right)$ with high-risk WC $(>88 \mathrm{~cm}$ in women; $>102 \mathrm{~cm}$ in men). Based on a WHtR of $\geq 0.5,19.7 \%$ $(n=15)$ of the men and $69.8 \%(n=183)$ of the women were

TABLE 1: Age, blood pressure and anthropometric measurements of participants ( $N=339$, unless indicated otherwise)

\begin{tabular}{|c|c|c|c|}
\hline Variable & Mean & $\begin{array}{c}\text { Standard } \\
\text { deviation (SD) }\end{array}$ & Range \\
\hline \multicolumn{4}{|l|}{ Age } \\
\hline Years & 44.3 & \pm 10.6 & $25-64$ \\
\hline \multicolumn{4}{|l|}{ Blood pressure (mmHg) } \\
\hline \multicolumn{4}{|l|}{ Systolic pressure } \\
\hline Total group & 135.5 & \pm 23.7 & $72-203$ \\
\hline Men $(n=76)$ & 134.8 & \pm 22.8 & $87-188$ \\
\hline Women $(n=263)$ & 135.7 & \pm 24.0 & $72-203$ \\
\hline \multicolumn{4}{|l|}{ Diastolic pressure } \\
\hline Total group & 89.8 & \pm 17.6 & $46-188$ \\
\hline Men $(n=76)$ & 86.6 & \pm 15.2 & $54-119$ \\
\hline Women $(n=263)$ & 90.7 & \pm 18.1 & $46-188$ \\
\hline \multicolumn{4}{|l|}{ Mean arterial pressure } \\
\hline Total group & 105.0 & \pm 18.0 & 59-191 \\
\hline Men $(n=76)$ & 102.7 & \pm 15.6 & $68-133$ \\
\hline Women $(n=263)$ & 105.7 & \pm 18.5 & 59-191 \\
\hline Height (cm) & 159.4 & \pm 7.9 & $139.8-180$ \\
\hline Weight (kg) & 70.1 & \pm 21.4 & $31.9-140$ \\
\hline \multicolumn{4}{|l|}{ Body mass index $\left(\mathrm{BMI} ; \mathrm{kg} / \mathrm{m}^{2}\right)$} \\
\hline Total group & 27.8 & \pm 8.8 & $13.3-55.7$ \\
\hline Men $(n=76)$ & 21.4 & \pm 5.6 & $14.5-49.9$ \\
\hline Women $(n=263)$ & 29.6 & \pm 8.7 & $13.3-55.7$ \\
\hline \multicolumn{4}{|l|}{ Waist circumference (WC; cm) } \\
\hline Men $(n=76)$ & 78.1 & \pm 13.9 & $47-134$ \\
\hline Women $(n=262)$ & 88.9 & \pm 17.1 & $59-143$ \\
\hline Waist-height ratio (WHtR) $(N=338)$ & 0.55 & \pm 0.11 & $0.27-0.91$ \\
\hline Hip circumference $(\mathrm{cm})(N=338)$ & 104.5 & \pm 18.2 & $73.5-165$ \\
\hline \multicolumn{4}{|l|}{ Body adiposity index (BAl; \%) } \\
\hline Men $(n=76)$ & 24.1 & \pm 5.2 & $16.8-50.7$ \\
\hline Women $(n=262)$ & 37.1 & \pm 9.5 & $19.2-66.1$ \\
\hline
\end{tabular}

at risk. When taking BAI into consideration, $73.7 \%(n=56)$ of the men and $77.1 \%(n=202)$ of the women had body fat percentages in the overweight/obese category.

\section{Occurrence of hypertension in relation to age, gender and body fat indices}

A major risk factor for increased arterial blood pressure is age. To assess the effect of age, participants were stratified according to mean age into two age groups, namely $>44$ years $(n=172)$ and $\leq 44$ years $(n=167)$. Hypertension was significantly more prevalent in the older group $\left(\chi^{2}=\right.$ 45.526; $p<0.0001)$. A relative risk for hypertension of 1.78 (95\% confidence interval [CI] $1.48 ; 2.13)$ was calculated, indicating that the older group had a $78 \%$ higher risk of being hypertensive than the younger group. When genders were compared, controlling for age, the relative risk for hypertension was $2.4(95 \%$ CI $1.47 ; 3.91)$ for men and $1.66(95 \%$ CI $1.37 ; 2.01)$ for women. The occurrence of hypertension in relation to BMI categories is shown in Table 3.

When stratified into low to normal BMI $\left(<25 \mathrm{~kg} / \mathrm{m}^{2}\right.$; low risk $)$ and overweight/obese BMI ( $\geq 25 \mathrm{~kg} / \mathrm{m}^{2}$; high risk), $76.5 \%$ ( $n=143$ ) of the overweight/obese group had hypertension, which was a significant finding $\left(\chi^{2}=30.611 ; p<0.0001\right)$ in this group. After controlling for age, participants $>44$ years with an overweight/obese BMI had a relative risk of 1.25 (95\% CI 1.06 ; 1.46$)$ of being hypertensive, compared with a normal/ underweight BMI. In the $\leq 44$ years group, the relative risk of being hypertensive was 2.69 (95\% CI 1.75; 4.15) when being overweight/obese versus being normal/underweight.

When applying a multivariate logistic regression model (mean arterial pressure as independent variable and age and BMI as dependent variables), BMI and age accounted for $14.8 \%$ of the change in arterial pressure. For every one year increase in age, or every $1 \mathrm{~kg} / \mathrm{m}^{2}$ increase in BMI, a $0.48 \mathrm{mmHg}$ increase in mean arterial pressure could be expected $(p<0.001)$.

TABLE 2 A: Body mass index (BMI) according to the categories recommended by the WHO for international classification. ${ }^{11}$

\begin{tabular}{|c|c|c|c|c|c|}
\hline \multirow[t]{2}{*}{$\mathrm{BMI} \mathrm{kg} / \mathrm{m}^{2}$} & \multirow[t]{2}{*}{ Classification } & \multicolumn{2}{|c|}{ Men $(n=76)$} & \multicolumn{2}{|c|}{ Women $(n=263)$} \\
\hline & & $n$ & $\%$ & $n$ & $\%$ \\
\hline$<18.5$ & Underweight & 19 & 25.0 & 21 & 8.0 \\
\hline $18.5-24.9$ & Normal & 43 & 56.6 & 69 & 26.2 \\
\hline $25.0-29.9$ & Overweight & 11 & 14.5 & 67 & 25.5 \\
\hline $30.0-34.9$ & Obese Class I & 0 & 0 & 39 & 14.8 \\
\hline $35.0-39.9$ & Obese Class 2 & 2 & 2.6 & 32 & 12.2 \\
\hline$\geq 40.0$ & Obese Class 3 & 1 & 1.3 & 35 & 13.3 \\
\hline
\end{tabular}

TABLE 2B: Waist circumference (WC) according to the categories recommended by the WHO. ${ }^{9}$

\begin{tabular}{|c|c|c|c|c|c|c|}
\hline \multirow[t]{2}{*}{ Level of risk } & \multirow{2}{*}{\multicolumn{2}{|c|}{ Gender-specific cut-offs }} & \multicolumn{2}{|c|}{ Men $(n=76)$} & \multicolumn{2}{|c|}{ Women $(n=262)$} \\
\hline & & & $n$ & $\%$ & $n$ & $\%$ \\
\hline Low risk & $\begin{array}{l}\text { Men: } \\
\text { Women: }\end{array}$ & $\begin{array}{l}<94 \mathrm{~cm} \\
<80 \mathrm{~cm}\end{array}$ & 71 & 93.4 & 87 & 33.2 \\
\hline Increased risk & $\begin{array}{l}\text { Men: } \\
\text { Women: }\end{array}$ & $\begin{array}{l}94-102 \mathrm{~cm} \\
80-88 \mathrm{~cm}\end{array}$ & 2 & 2.6 & 59 & 22.5 \\
\hline High risk (central obesity) & $\begin{array}{l}\text { Men: } \\
\text { Women: }\end{array}$ & $\begin{array}{l}>102 \mathrm{~cm} \\
>88 \mathrm{~cm}\end{array}$ & 3 & 3.9 & 116 & 44.3 \\
\hline
\end{tabular}

TABLE 2C: Waist-to-height ratio (WHtR). ${ }^{16}$

\begin{tabular}{|c|c|c|c|c|c|}
\hline \multirow[t]{2}{*}{ Level of risk } & \multirow[t]{2}{*}{ Universal cut-offs } & \multicolumn{2}{|c|}{ Men $(n=76)$} & \multicolumn{2}{|c|}{ Women $(n=262)$} \\
\hline & & $n$ & $\%$ & $n$ & $\%$ \\
\hline Low risk & $<0.5$ & 61 & 80.3 & 79 & 30.2 \\
\hline At risk & $\geq 0.5$ & 15 & 19.7 & 183 & 69.8 \\
\hline
\end{tabular}


TABLE 2D: Body adiposity index (BAI) according to body fat $\%$ categories. $^{29}$

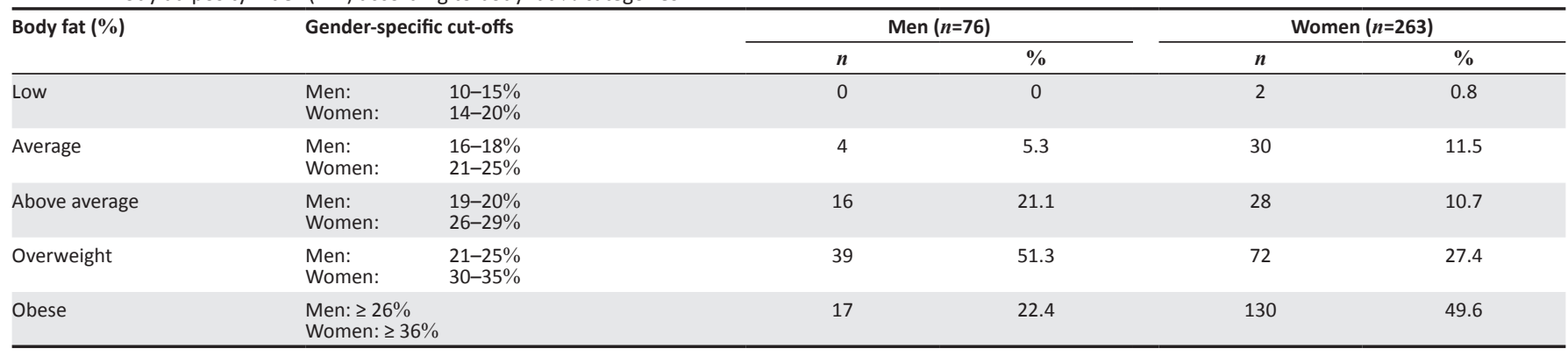

TABLE 3: Distribution of normotensive and hypertensive participants across BMI categories.

\begin{tabular}{|c|c|c|c|c|}
\hline \multirow[t]{2}{*}{ Body mass index (BMI) } & \multicolumn{2}{|c|}{ Normotensive $(n=124)$} & \multicolumn{2}{|c|}{ Hypertensive $(n=215)$} \\
\hline & $n$ & $\%$ & $n$ & $\%$ \\
\hline \multicolumn{5}{|l|}{ Weight } \\
\hline Underweight $\left(<18.5 \mathrm{~kg} / \mathrm{m}^{2}\right)$ & 23 & 18.5 & 17 & 7.9 \\
\hline Normal weight $\left(18.5-24.9 \mathrm{~kg} / \mathrm{m}^{2}\right)$ & 57 & 46.0 & 55 & 25.6 \\
\hline Overweight $\left(25.0-29.9 \mathrm{~kg} / \mathrm{m}^{2}\right)$ & 23 & 18.5 & 55 & 25.6 \\
\hline \multicolumn{5}{|l|}{ Obese } \\
\hline Class I $\left(30.0-34.9 \mathrm{~kg} / \mathrm{m}^{2}\right)$ & 5 & 4.0 & 34 & 15.8 \\
\hline Class II $\left(35.0-39.9 \mathrm{~kg} / \mathrm{m}^{2}\right)$ & 6 & 4.8 & 28 & 13.0 \\
\hline Class III ( $\left.\geq 40 \mathrm{~kg} / \mathrm{m}^{2}\right)$ & 10 & 8.1 & 26 & 12.1 \\
\hline
\end{tabular}

TABLE 4: Waist circumference in relation to the prevalence of hypertension.

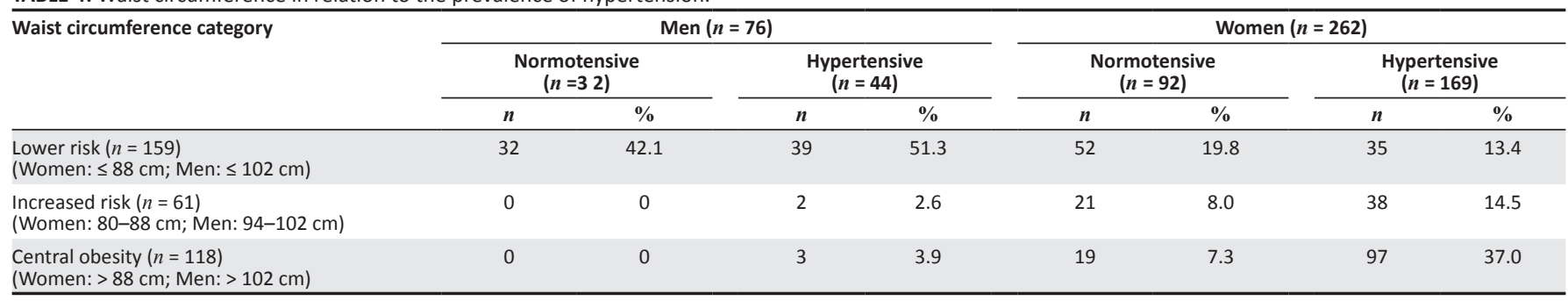

In Table 4, the prevalence of hypertension according to WC categories is summarised, indicating an increased prevalence of hypertension with increasing WC for women $\left(\chi^{2}=32.062\right.$; $p<0.0001)$. An independent samples $t$-test confirmed that WC in the hypertensive group was significantly higher than the normotensive group and correlations showed that mean arterial blood pressure correlated significantly with WC in both men $(r=0.262 ; p<0.05)$ and women $(r=0.382 ; p<0.001)$.

When female participants were stratified according to WC as $>88 \mathrm{~cm}$ and $\leq 88 \mathrm{~cm}$ and controlled for age $(<44$ years and $\geq 44$ years), older women with high-risk WC had a relative risk of 1.29 (95\% CI 1.08; 1.53) of being hypertensive; whilst younger women with high-risk WC had a relative risk of 2.22 (95\% CI $1.56 ; 3.14)$ of being hypertensive.

Both WHtR $(r=0.357 ; p<0.001)$ and BAI $(r=0.245$; $p<0.001)$ correlated significantly with mean arterial blood pressure. A significant relation was found between a WHtR of $\geq 0.5$ (increased risk) and the prevalence of hypertension $\left(\chi^{2}=43.057 ; p<0.001\right)$. WHtR $(r=0.357)$ showed a stronger correlation with mean arterial pressure than BMI $(r=0.261)$ or BAI $(r=0.245)$.

\section{HIV status and blood pressure}

Mean arterial pressure was correlated inversely to HIV status $(r=-0.217 ; p<0.001)$. However, partial correlation indicated that this inverse association resulted from the effect of age and adiposity levels on blood pressure. When using a point bi-serial correlation, HIV status showed an inverse correlation with BMI $(r=-0.262 ; p<0.001)$, WC $(r=-0.364$; $p<0.001)$, WHtR $(r=-0.299 ; p<0.001)$, and BAI $(r=-0.226$; $p<0.001)$ in women.

\section{Discussion}

The prevalence of hypertension, which affected $63.4 \%$ of the total group in this low-income, urban, black population, compares with $61.8 \%$ reported for an African-American population older than 40 years. ${ }^{30}$ The high prevalence of hypertension, especially amongst a population that included younger participants, raises concern.

More than half $(55.1 \% ; n=187)$ of the participants had BMIs above normal (23.0\% overweight; $32.1 \%$ obese). This is higher than the WHO estimate of $45.1 \%$ for the prevalence of overweight/obesity in the general South African population ${ }^{27}$ and the $48 \%$ reported for South Africans from 18 companies participating in a health-risk screening programme. ${ }^{31}$ For men, the prevalence of overweight/obesity was lower (18.4\%) than the prevalence described for Free State men in the South African National Health and Nutrition Examination Survey study $(25.3 \%)$, but for women, the prevalence was higher $(65.8 \%$ vs $63.7 \%){ }^{32}$ The mean BMI for this study $\left(27.8 \mathrm{~kg} / \mathrm{m}^{2}\right)$ 
was lower than the mean of $29.8 \pm 0.2 \mathrm{~kg} / \mathrm{m}^{2}$ for Americans of combined races,,$^{30}$ as well as the mean of $30.1 \mathrm{~kg} / \mathrm{m}^{2}$ in African-Americans as reported previously. ${ }^{33}$

With regard to above-normal BMIs, $14.5 \%(n=11)$ and 3.9\% $(n=3)$ of men (mean BMI $\left.21.4 \mathrm{~kg} / \mathrm{m}^{2}\right)$ and $25.5 \%(n=67)$ and $40.3 \%(n=106)$ of women (mean BMI $\left.29.6 \mathrm{~kg} / \mathrm{m}^{2}\right)$ were overweight and obese, respectively. This finding corresponds with data from the South African Demographic and Health Survey, ${ }^{34}$ reporting $18.7 \%$ of urban black men as overweight and $8.1 \%$ as obese (mean BMI $23.1 \mathrm{~kg} / \mathrm{m}^{2}$ ) and $27.1 \%$ of urban black women as overweight and $33.8 \%$ as obese (mean BMI $\left.28.1 \mathrm{~kg} / \mathrm{m}^{2}\right)$. Our findings confirmed the trend that black South African women have substantially higher BMIs than their male counterparts, as reported previously. Charlton et al. ${ }^{35}$ reported a mean BMI of $28 \mathrm{~kg} / \mathrm{m}^{2}$ in black South African men $\left(37.7 \%\right.$ obese) and $33.5 \mathrm{~kg} / \mathrm{m}^{2}$ in black South African women $(67.9 \%$ obese) in Cape Town. The Transition and Health During Urbanisation of South Africans (THUSA) study $^{36}$ reported that $28.6 \%$ of black South African female participants were obese and $53.8 \%$ had a BMI $>25 \mathrm{~kg} / \mathrm{m}^{2}$. Contrary to the higher BMIs found amongst women in South Africa, a mean BMI of $26.4 \mathrm{~kg} / \mathrm{m}^{2}$ for American men and $26.2 \mathrm{~kg} / \mathrm{m}^{2}$ for women have been reported. ${ }^{37}$

The high prevalence of overweight/obesity in this population, linked to the prevalence of hypertension, agrees with the International Study of Salt and Blood Pressure (INTERSALT), ${ }^{38}$ reporting a strong, significant, independent association of BMI with blood pressure.

BMI in this study was related significantly $(p<0.001)$ to to WC. Black South African women had a similar mean WC $(88.9 \mathrm{~cm})$ than American women $(88.5 \mathrm{~cm}){ }^{37}$ In contrast, black South African men in our study had a lower mean WC $(78.1 \mathrm{~cm})$ than American men $(95.6 \mathrm{~cm})$. The incidence of high-risk WC was higher than the national data for urban black South Africans ${ }^{34}$ (3.9\% versus 3.1\% for men; and 44.3\% versus $39.1 \%$ for women). Charlton et al ${ }^{35}$ also described a higher mean WC in a black population, namely $92.6 \mathrm{~cm}$ in men and $92.4 \mathrm{~cm}$ in women.

Mashele et al. ${ }^{39}$ found that, similar to our findings, urbanised hypertensive black South African men and women were typically older, more obese and had a larger WC compared with their normotensive counterparts.

Based on WHtR and BAI as obesity indices, a high percentage of participants in the current study were at increased risk for NCD. WHtR was increased in $58.6 \%(n=198)$ of participants, whilst $76.3 \%(n=258)$ of all participants had a BAI in the overweight/obese category. We found a slightly stronger association of hypertension with WHtR than with BMI and BAI, although all three indices were associated significantly with mean arterial blood pressure. These findings concur with a meta-analysis ${ }^{40}$ reporting that measures of abdominal obesity were better predictors of cardiovascular disease risk than BMI. More importantly, however, WHtR could be seen as a simple tool to screen for hypertension in this particular community. At a primary healthcare level, the community could be taught to use a piece of string equal to their height; if the string cannot go around the waist at least twice, the risk for hypertension and other non-communicable diseases is reflected.

Almost $40 \%(n=135)$ of participants in our study were infected with HIV. Although the prevalence of hypertension showed an inverse association with HIV status, this association was found to result from the lower body adiposity as represented by lower BMI, WHtR, BAI and WC, which are associated with HIV infection. A similar lack of significant associations between hypertension and HIV status has been reported previously..$^{19,20,21,22,23}$

A degree of bias is acknowledged. More women may have participated because the research was conducted during a week day, resulting in less men attending because of being formally employed. More ill people may have participated due to free medical examinations being conducted during the study.

\section{Conclusion}

Obesity, hypertension and HIV occurred commonly amongst participants in this study. The prevalence of hypertension was not influenced significantly by HIV status when adiposity was taken into account. WHtR was related significantly to mean arterial pressure and seemed to be a stronger predictor of mean arterial pressure than BMI or BAI. Obesity was more prevalent in women than men; and, in women, hypertension was related significantly to WC and BMI. These results support weight loss as the first line of intervention for the treatment and prevention of hypertension with its accompanying disease burden. We propose that WHtR may be an easy and practical way of screening for hypertension and motivating communities to decrease their waist circumference. Future research to assess the impact of a simple nutrition message, 'Stay healthy by keeping your waist circumference less than half of your height', is recommended.

\section{Acknowledgements}

The researchers acknowledge the Department of Biostatistics, Faculty of Health Sciences, University of the Free State, for providing assistance with the analysis and interpretation of data. The Fulbright program (USA) is acknowledged for research assistance during writing of the report. Dr. Daleen Struwig, medical writer, Faculty of Health Sciences, UFS, is acknowledged for technical and editorial preparation of the manuscript for publication.

The study received financial support from the South African National Research Foundation (NRF); grant number TTK2006050800013.

\section{Competing interests}

The authors declare that they have no financial or personal relationship(s) which may have influenced them inappropriately in writing this article. 


\section{Authors' contributions}

R.L. (University of the Free State) planned the project, collected and interpreted data, performed part of the statistical analysis and wrote the article; V.L.vdB. (University of the Free State) was the study leader, made substantial scientific contributions and assisted in writing the article; and C.W. (University of the Free State) was the co-study leader, the principle investigator of the larger AHA-FS study, collected and interpreted data and assisted in writing the article. All the authors approved the final version of the manuscript.

\section{References}

1. Couch SC, Krummel DA. Medical nutrition therapy for hypertension. In: Mahan KL, Escott-Stump S, editors. Krause's food and nutrition therapy. 12th ed. Philadelphia: Escott-Stump S, editors. Krause's food and

2. Norman R, Gaziano T, Laubscher R, et al. Estimating the burden of disease attributable to high blood pressure in South Africa in 2000. S Afr Med J. 2007;97(8 Pt 2):692-698. PMID: 17952226

3. Steyn K. Hypertension in South Africa. In: Steyn K, Fourie J, Temple N, editors. Chronic diseases of lifestyle: 1995-2005. Technical report. Cape Town: South African Medical Research Council, 2006; p. 80-96.

4. Hu G, Jousilahti P, Antikainen R, et al. Joint effects of physical activity, body mass index, waist circumference, and waist-to-hip ratio on the risk of heart failure. Circulation 2010;121:237-244. http://dx.doi.org/10.1161/CIRCULATIONAHA.109.887893, PMid: 20048205

5. Yatsuya $\mathrm{H}$, Folsom AR, Yamagishi $\mathrm{K}$, et al. Race- and sex-specific associations of obesity measures with ischemic stroke incidence in the Atherosclerosis Risk in Communities (ARIC) Study. Stroke 2010;41(3):417-425. http://dx.doi.org/10.1161/ Communities (ARIC) Study. Stroke 2010;41(3):
STROKEAHA.109.566299, PMid: 20093637

6. Appel L. ASH position paper: dietary approaches to lower blood pressure. J Clin Hypertens. 2009;11(7):358-368. http://dx.doi.org/10.1111/j.17517176.2009.00136.x, PMid: 19583632

7. Neter JE, Stam BE, Kok FJ, et al. Influence of weight reduction on blood pressure: meta-analysis of randomized controlled trials. Hypertension. 2003;42(5):878-884. http://dx.doi.org/10.1161/01.HYP.0000094221.86888.AE, PMid: 12975389

8. Nordstrand N, Gjevestad E, Dinh KN, et al. The relationship between various measures of obesity and arterial stiffness in morbidly obese patients. BMC Cardiovasc Disord. 2011;11:7. http://dx.doi.org/10.1186/1471-2261-11-7, PMid: 21284837

9. World Health Organization. Waist circumference and waist-hip ratio: report of a WHO expert consultation, Geneva, 8-11 December 2008 [document on of a WHO expert consultation, Geneva, 8-11 December 2008 [document on
the internet]. c2011 [cited 2011 Jun 7]. Available from: whqlibdoc.who.int/ the internet]. c2011 [cited 2011 Jun 7].
publications/2011/9789241501491_eng.pdf

10. Levine DA, Calhoun DA, Prineas RJ, et al. Moderate waist circumference and hypertension prevalence: the REGARDS study. Am J Hypertens. 2011;24(4):482488. http://dx.doi.org/10.1038/ajh.2010.258, PMid: 21233800

11. WHO Expert Consultation. Appropriate body-mass index for Asian populations and its implications for policy and intervention strategies. Lancet. 2004;363(9403):157163. http://dx.doi.org/10.1016/S0140-6736(03)15268-3, PMid: 14726171

12. Alberti KG, Eckel RH, Grundy SM, et al. Harmonizing the metabolic syndrome: a joint interim statement of the International Diabetes Federation Task Force on Epidemiology and Prevention; National Heart, Lung, and Blood Institute; American Heart Association; World Heart Federation; International Atherosclerosis Society; and International Association for the Study of Obesity. Circulation. 2009;120(16):1640-
1645. http://dx.doi.org/10.1161/CIRCULATIONAHA.109.192644, PMid: 19805654

13. Eckel RH, Grundy SM, Zimmet PZ. The metabolic syndrome. Lancet. 2005;365(9468):1415-1428. http://dx.doi.org/10.1016/\$0140-6736(05)66378-7, PMid: 15836891

14. Balkau B, Charles MA. Comment on the provisional report from the WHO consultation. European Group for the Study of Insulin Resistance (EGIR). Diabet Med. 1999;16(5):442-443. http://dx.doi.org/10.1046/j.1464-5491.1999.00059.x, PMid: 10342346

15. Ashwell M, Hsieh SD. Six reasons why the waist-to-height ratio is a rapid and effective global indicator for health risks of obesity and how its use could simplify the international public health message on obesity. Int J Food Sci Nutr. 2005;56(5):303307. http://dx.doi.org/10.1080/09637480500195066, PMid: 16236591

16. Sayeed MA, Mahtab H, Latif ZA, et al. Waist-to-height ratio is a better obesity index than body mass index and waist-to-hip ratio for predicting diabetes, hypertension and lipidemia. Bangladesh Med Res Counc Bull. 2003;29(1):1-10. PMid: 14674615

17. Bergman RN, Stefanovski D, Buchanan TA, et al. A better index of body adiposity. Obesity. 2011;19(5):1083-1089. http://dx.doi.org/10.1038/oby.2011.38, PMid: 21372804

18. Schutte AE, Huisman HW, Van Rooyen JM, et al. Should obesity be blamed for the high prevalence rates of hypertension in black South African women? J Hum Hypertens. 2008;22(8):528-536. http://dx.doi.org/10.1038/jhh.2008.35, PMid: 18432254
19. Medina-Torne S, Ganesan A, Barahona I, et al. Hypertension is common among HIV-infected persons, but not associated with HAART. J Int Assoc Physicians AIDS Care. 2012;11(1):20-25. http://dx.doi.org/10.1177/1545109711418361, PMid: 21876213

20. Bloomfield GS, Hogan JW, Keter A, et al. Hypertension and obesity as cardiovascular risk factors among HIV seropositive patients in Western Kenya. PLoS ONE. 2011;6(7):e22288. http://dx.doi.org/10.1371/journal.pone.0022288, PMid: 21779407

21. Baekken M, Os I, Sandvik L, et al. Hypertension in an urban HIV-positive population compared with the general population: influence of combination antiretroviral therapy. J Hypertens. 2008;26(11):2126-2133. http://dx.doi.org/10.1097/ HJH.0b013e32830ef5fb, PMid: 18854751

22. Jung $O$, Bickel $M$, Ditting $T$, et al. Hypertension in HIV-1-infected patients and its impact on renal and cardiovascular integrity. Nephrol Dial-Transplant. 2004;19(9):2250-2258. http://dx.doi.org/10.1093/ndt/gfh393, PMid: 15238630

23. Bergersen BM, Sandvik L, Dunlop O, et al. Prevalence of hypertension in HIVpositive patients on highly active retroviral therapy (HAART) compared with HAART-naïve and HIV-negative controls: results from a Norwegian study of 721 patients. Eur J Clin Microbiol Infect Dis. 2003;22(12):731-736. http://dx.doi. org/10.1007/s10096-003-1034-z, PMid: 14610658

24. Van Zyl S, Van der Merwe L, Walsh CM, et al. Risk-factor profiles for chronic diseases of lifestyle and metabolic syndrome in an urban and rural setting in South Africa. Afr J Prim Health Care Fam Med. 2012;4(1), Art. \#346, 10 pages. http:// dx.doi.org/10.4102/phcfm.v4i1.346

25. Wallace $C$, Xue $M Z$, Caulfield $M$, et al. Genome scans in hypertension. In: Dominiczak AF, Connell JMC, editors. Handbook of hypertension, vol. 24. Genetics of hypertension. Edinburgh: Elsevier, 2007, p. 49-66.

26. National Institutes of Health; National Heart, Lung, and Blood Institute; National High Blood Pressure Education Program (NIH). The seventh report of the joint national committee on prevention, detection, evaluation, and treatment of high blood pressure [document on the internet]. c2004 [cited 2013 May 10]. Available from: http://www.nhlbi.nih.gov/guidelines/hypertension/jnc7full.pdf

27. World Health Organization. WHO STEPS surveillance: guide to physical measurements. Step 3: guide to physical measurements (step 2) [document on the internet]. c2008 [cited 2011 Jun 7]. Available from: www.who.int/chp/steps/ Part3_Section3.pdf

28. World Health Organization. Global database on body mass index 2011 [homepage on the internet]. c2011 [cited 2011 Feb 21].Available from: http://apps.who.int/ bmi/index.jsp?introPage=intro_3.html

29. Ricciardi R, Metter EJ, Cavanaugh EW, et al. Predicting cardiovascular risk using measures of regional and total body fat. Appl Nurs Res. 2009;22(1):2-9. http:// dx.doi.org/10.1016/j.apnr.2007.01.011, PMID: 19171289

30. Reis JP, Michos ED, Von Mühlen D, et al. Differences in vitamin D status as a possible contributor to the racial disparity in peripheral arterial disease. Am J Clin Nutr. 2008;88(6):1469-1477. http://dx.doi.org/10.3945/ajcn.2008.26447, PMid 19064505

31. Kolbe-Alexander TL, Buckmaster C, Nossel C, et al. Chronic disease risk factors, healthy days and medical claims in South African employees presenting for health risk screening. BMC Public Health 2008;8:228. http://dx.doi.org/10.1186/1471 2458-8-228, PMid: 18601718

32. Shisana O, Labadarios D, Rehle T, et al. The South African National Health and Nutrition Examination Survey (SANHANES-1). [document on the internet]. c2013 [cited 2013 Oct 30]. Available from: http://www.hsrc.ac.za/uploads/ pageContent/3893/SANHANES-launch\%20edition\%20(online\%20version).pdf

33. Ehret GB, Morrison AC, O'Connor AA, et al. Replication of the Wellcome Trust genome-wide association study of essential hypertension. Eur J Human Genet 2008;16(12):1507-1511. http://dx.doi.org/10.1038/ejhg.2008.102, PMid: 18523456

34. Department of Health. South Africa Demographic and Health Survey 2003, full report. Pretoria: Department of Health; 2007. Available from: www.mrc.ac.za/ bod/sadhs.htm

35. Charlton KE, Steyn K, Levitt NS, et al. Diet and blood pressure in South Africa: intake of foods containing sodium, potassium, calcium, and magnesium in three ethnic groups. Nutrition. 2005;21(1):39-50. http://dx.doi.org/10.1016/j. nut.2004.09.007, PMid: 15661477

36. Kruger HS, Venter CS, Vorster HH, et al. Physical inactivity is the major determinant of obesity in black women in the North West Province, South Africa: the THUSA study. Nutrition. 2002;18(5):422-427. http://dx.doi.org/10.1016/S08999007(01)00751-1, PMID: 11985949

37. Flegal KM, Graubard BI. Estimates of excess deaths associated with body mass index and other anthropometric variables. Am J Clin Nutr. 2009;89(4):1213-1219. http://dx.doi.org/10.3945/ajcn.2008.26698, PMid: 19190072

38. Intersalt Cooperative Research Group. Intersalt: an international study of electrolyte excretion and blood pressure. Results for 24 hour urinary sodium and potassium excretion. BMJ. 1988;297(6644):319-328. http://dx.doi.org/10.1136/ potassium excretion. BMJ. 1988;2971

39. Mashele N, Van Rooyen JM, Malan L, et al. Cardiovascular function and psychological distress in urbanised black South Africans: the SABPA study. psychological distress in urbanised black South Africa

40. Lee CM, Huxley RR, Wildman RP, et al. Indices of abdominal obesity are better discriminators of cardiovascular risk factors than BMI: a metaanalysis. J Clin Epidemiol. 2008;61(7):646-653. http://dx.doi.org/10.1016/j. jclinepi.2007.08.012, PMid: 18359190 